\title{
Effects of Photoradiation on the Growth and Potassium, Calcium, and Magnesium Uptake of Lettuce Cultivated by Hydroponics
}

\author{
Nur Ainun ${ }^{1}$, Somsak Maneepong ${ }^{2} \&$ Potjamarn Suraninpong ${ }^{2}$ \\ ${ }^{1}$ Faculty of agriculture, Tadulako University, Palu, Sulawesi, Indonesia \\ ${ }^{2}$ School of Agricultural Technology, Walailak University, Nakhon Si Thammarat, Thailand \\ Correspondence: Somsak Maneepong, School of Agricultural Technology, Walailak University, Nakhon Si \\ Thammarat, 80161, Thailand. E-mail: msomsak2012@gmail.com
}

\author{
Received: March 7, $2018 \quad$ Accepted: April 8, $2018 \quad$ Online Published: May 15, 2018 \\ doi:10.5539/jas.v10n6p253 URL: https://doi.org/10.5539/jas.v10n6p253
}

The research is financed by Walailak University, Thailand.

\begin{abstract}
Photoradiation plays a major role in plant growth processes, especially photosynthesis and nutrient uptake. Light intensity and photoperiod affect temperature and caused more transpiration in plants, which influences nutrient uptake. This study aimed to examine the effects of photoradiation on the growth and $\mathrm{K}, \mathrm{Ca}$, and $\mathrm{Mg}$ uptake of lettuce (Lactuca sativa L.). Lettuce was hydroponically grown in a walk-in growth chamber, and the experiment was performed using eight treatments with eight replications. A combination of eight fluorescent lamps was used to provide a photon flux density of $128 \pm 20 \mu$ mole $\mathrm{m}^{-2} \mathrm{~s}^{-1}$ for $15 / 15$ minutes, $45 / 15$ minutes, $345 / 15+15 / 15$ minutes of black UV, and 345/15+15/45 minutes of black UV of light/dark periods. A combination of ten fluorescent lamps was used to provide a photon flux density of $194 \pm 28 \mu$ mole $\mathrm{m}^{-2} \mathrm{~s}^{-1}$ for $30 / 30$ minutes, $15 / 15$ minutes, and 45/15 minutes of light/dark periods and 24 hours of light period. Continuous illumination with higher light intensity gave the greatest shoot fresh weight, plant height and number of leaves. Whereas a shorter photoperiod and lower light intensity gave the lowest shoot fresh weight. Shortened UV light radiation gave better result in lettuce growth performance such as shoot fresh weight, plant height and number of leaves. UV light also damaged the lettuce leaves. The leaves turned brown (brown spot) at the tip of the old leaves. Molar concentrations of $\mathrm{K}, \mathrm{Ca}$ and $\mathrm{Mg}$ in the lettuce leaves were in the order of $\mathrm{K}>\mathrm{Ca}>\mathrm{Mg}$ for all of the treatments. The steep gradient and highest $\mathrm{K}$ accumulation at bottom leaves were found at lower light intensity and short photoperiod (15/15 minutes of light/dark). Extended photoperiod improved $\mathrm{K}$ and Ca movement and reduced $\mathrm{K}$ and $\mathrm{Ca}$ accumulation in the bottom leaves. High $\mathrm{K}$ in the leaves reduced $\mathrm{Ca}$ uptake. Continuous illumination with higher light intensity resulted in the lowest concentrations of $\mathrm{K}, \mathrm{Ca}$ and $\mathrm{Mg}$. The mole ratio of $\mathrm{K} / \mathrm{Ca}$ decreased from the top to bottom leaves, whereas the mole ratio of $\mathrm{K} / \mathrm{Mg}$ tended to be stable except in the treatment with lower light intensity and short photoperoid. The best growth performance was found in the treatment with consistent $\mathrm{K} / \mathrm{Ca}$ ratio.
\end{abstract}

Keywords: photoradiation, light intensity, nutrient uptake, soilless, lettuce

\section{Introduction}

Urban farming provides fresh food to customers, reduce loss of products and reduce cost of transportation. However, the cost and limitations of land areas can be minimized through intensive cultivation. Growing plants under controlled environment have a number of advantages, such as higher quality of yields, shorter production periods, and smaller labor force, relative to conventional growing systems (Kozai, 2013; Kang, Krishna Kumar, Atulba, Jeong, \& Hwang, 2013). The fresh weight of turnip can be increased by more than 10 times within 1 week when it was grown under a continuous illumination of $237 \mu \mathrm{mol} \mathrm{m} \mathrm{s}^{-1}$ and elevated $\mathrm{CO}_{2}$ concentration to $2100 \mu \mathrm{L} \mathrm{L}^{-1}$ (Ikeda, Nakayama, Kitaya, \& Yabuki, 1988). Sunlight is unsuitable for multilayer cultivation and has various limitations such as its limited availability only in the daytime and its inconsistant intensity. Plants do not require the whole spectrum. Infrared produces heat, therefore a cooling system has to be installed in tropical greenhouses. Artificial light from high-pressure Na lamps, fluorescent lamps or light-emitting diodes (LEDs) have to be introduced to solve such problems. Responses to continuous illumination depend on plant species. 
The reproduction cycle of long-day plants can be accelerated by extended illumination, but short-day plants do not respond in the same way. Extended photoperiod may cause leaf chlorosis and growth reduction in some plant species. Accumulation of starch and soluble carbohydrates occurs under continuous illumination, which possibly related to photooxidative damage of sensitive plants. This damage can be prevented through temperature alternation (Sysoeva, Markovskaya, \& Shibaeva, 2010). Increasing light intensity from $200 \mu \mathrm{mol} \mathrm{m} \mathrm{s}^{-1}$ to 290 $\mu \mathrm{mol} \mathrm{m} \mathrm{s}^{-1}$ increases fresh weight, leaf area, and number of leaves of lettuce grown under mixed LEDs (8:1:1 of red:blue:white) and $500 \mu \mathrm{mol} \mathrm{mol}^{-1} \mathrm{CO}_{2}$ (Kang et al., 2013).

Lettuce is not indigenous to tropical region. It is typically grown in low temperature and low light intensity (Frantz, Ritchie, Cometti, Robinson, \& Bugbee, 2004). Increasing the growth rate of plants by raising temperature and light intensity tends to elevate $\mathrm{Ca}$ requirement. $\mathrm{Ca}$ is supplied to new emergent leaves through the xylem depending on the transpiration rate. New lettuce leaves are generally located in the interior of older leaves. Therefore, the transpiration rate is restricted and Ca deficiency is easily occured. Barta and Tibbitts (2000) demonstrated that $\mathrm{Ca}$ deficiency (tipburn) of lettuce occurred only at young leaves enclosed by surrounding leaves and are consequently not exposed to light and ambient atmosphere. The increase in Ca concentration is more rapid in light exposed leaves than in enclosed leaves. Necrosis first occurs at the leaf tip, where $\mathrm{Ca}$ concentration decreases to around $0.4 \mathrm{~g} \mathrm{~kg}^{-1}$ dry weight. Frantz et al. (2004) demonstrated that the tipburn of lettuce can be eliminated by aeration onto meristems.

$\mathrm{Ca}$ uptake is not only affected by transpiration environment, but antagonistic effects of $\mathrm{K}^{+}, \mathrm{Mg}^{2+}$ and $\mathrm{NH}_{4}{ }^{+}$in culture solution also. Barta and Tibbitts (1991) found that Mg concentrations in tipburn leaves are higher than those in non-tipburn leaves, and $\mathrm{Mg}$ is negatively correlated with $\mathrm{Ca}$. Increasing of $\mathrm{K} / \mathrm{Ca}$ ratio in a culture solution decreased $\mathrm{Ca}$ concentrations in both leaves and roots of chicory. Increasing the ratio above 6/3 reduces yield and causes physiological disorders because of Ca deficiency (Zamaniyan \& Motallebic-Azar, 2012). The symptom of $\mathrm{Ca}$ deficiency (blossom-end rot) in tomato grown by rockwool culture increases as $\mathrm{Mg}$ concentration increases in a low Ca solution, but not in a high Ca solution (Hao \& Papadopoulos, 2003). The present study was conducted to examine the effects of photoradiation on the growth and $\mathrm{K}$, $\mathrm{Ca}$ and $\mathrm{Mg}$ uptake of lettuce.

\section{Materials and Methods}

The study was conducted under controlled growing condition using lettuce (Lactuca sativa L.) as a test plant. Lettuce was grown by a deep flow technique (DFT) in a $54 \mathrm{~cm}$ width, $60 \mathrm{~cm}$ length and $10 \mathrm{~cm}$ depth of growing basin. Plant roots were immersed in a nutrient solution having a depth of $8 \mathrm{~cm}$. The solution was aerated via a couple of $25 \mathrm{~cm}$ air diffusers and circulated around the roots by using an aquarious pump. The composition of nutrient solution was: $\mathrm{N}\left(13.50 \mathrm{mM} \mathrm{NO}_{3}{ }^{-}\right.$and $\left.0.90 \mathrm{mM} \mathrm{NH}_{4}{ }^{+}\right), \mathrm{P}(1.50 \mathrm{mM}), \mathrm{K}(6.00 \mathrm{mM}), \mathrm{Ca}(4.50 \mathrm{mM}), \mathrm{Mg}$ (2.00 mM), S (2.45 mM), Fe (45.00 $\mu \mathrm{M}), \mathrm{Mn}(10.00 \mu \mathrm{M}), \mathrm{Cu}(0.75 \mu \mathrm{M}), \mathrm{Zn}(1.80 \mu \mathrm{M}), \mathrm{B}(35 \mu \mathrm{M})$ and Mo $(0.25$ $\mu \mathrm{M})$. The initial $\mathrm{pH}$ of the solution was about 6.5 . The electrical conductivity (EC) of the solution was maintained at $2.0 \pm 0.2 \mathrm{dS} \mathrm{m}^{-1}$. Growing shelves were vertically installed inside a growth chamber. Light source supplied by white fluorescent lamps and black UV light at 8 light treatments (Table 1). The lamps were installed $30 \mathrm{~cm}$ above growing panels. LeKise fluorescent lamps (28 W T5 2800 lumen) and black UV lights (Akoda BLB 40/T10 - 40 watt -48 inch black light tube) were used. A combination of 8 lamps provided photon flux density of $128 \pm 20 \mu$ mole $\mathrm{m}^{-2} \mathrm{~s}^{-1}$, and 10 lamps provided $194 \pm 28 \mu$ mole $\mathrm{m}^{-2} \mathrm{~s}^{-1}$ above the growing panels.

\subsection{Plant Culture}

Lettuce seeds were germinated on cocopeat. When the first true leaves emerge, half strength nutrient was supplied before transplanted. The seedlings were transplanted on a growing panel of $20 \mathrm{~cm} \times 20 \mathrm{~cm}$ density at 21 days after germination. The growth chamber was maintained at $16 \pm 1{ }^{\circ} \mathrm{C}$ and $68 \pm 7 \%$ relative humidity (RH). Temperature above the growing panels was measured daily. Plant height was measured weekly, and number of leaves were counted weekly. The lettuce was harvested at 43 days after germination. 
Table 1. Number of lamps, mean light intensity, and photocycle of illumination for each treatment

\begin{tabular}{|c|c|c|c|c|c|c|c|}
\hline \multirow{3}{*}{ Treatments } & \multirow{2}{*}{\multicolumn{2}{|c|}{ Number of lamp }} & \multirow{3}{*}{$\begin{array}{l}\text { Intensity } \\
(\text { mean } \pm \text { SD }) \\
\left(\mu \mathrm{mol} \mathrm{m} \mathrm{s}^{-1}\right)\end{array}$} & \multicolumn{4}{|c|}{ Photocycle (on-off) } \\
\hline & & & & \multicolumn{2}{|c|}{ Fluorescent } & \multicolumn{2}{|c|}{ UV } \\
\hline & Fluorescent & UV & & Light & Dark & Light & Dark \\
\hline 1 & 10 & 0 & $194 \pm 28$ & $30 \mathrm{~min}$ & $30 \mathrm{~min}$ & - & - \\
\hline 2 & 10 & 0 & $194 \pm 28$ & $15 \mathrm{~min}$ & $15 \mathrm{~min}$ & - & - \\
\hline 3 & 8 & 0 & $128 \pm 20$ & $15 \mathrm{~min}$ & $15 \mathrm{~min}$ & - & - \\
\hline 4 & 8 & 1 & $128 \pm 20$ & $345 \mathrm{~min}$ & $15 \mathrm{~min}$ & $15 \mathrm{~min}$ & $15 \mathrm{~min}$ \\
\hline 5 & 10 & 0 & $194 \pm 28$ & $45 \mathrm{~min}$ & $15 \mathrm{~min}$ & - & - \\
\hline 6 & 10 & 0 & $194 \pm 28$ & $24 \mathrm{~h}$ & - & - & - \\
\hline 7 & 8 & 0 & $128 \pm 20$ & $45 \mathrm{~min}$ & $15 \mathrm{~min}$ & - & - \\
\hline 8 & 8 & 1 & $128 \pm 20$ & $345 \mathrm{~min}$ & $15 \mathrm{~min}$ & $15 \mathrm{~min}$ & $45 \mathrm{~min}$ \\
\hline
\end{tabular}

\subsection{Leaf Sampling and Analysis}

After lettuce was harvested from the growing bed, the roots were removed, and their fresh weight was measured. Leaf samples were separated into 10 to 15 sections counted from the top leaf to the bottom leaf because of the different number of leaves. The samples were packed into paper bags, dried in a hot air oven at $65^{\circ} \mathrm{C}$ for 1 week, ground, and pass through a $1 \mathrm{~mm}$ sieve for nutrient composition analysis. Dried samples of $0.25 \mathrm{~g}$ were digested in $125 \mathrm{~mL}$ erlenmeyer flasks with $10 \mathrm{~mL}$ of mixed $\mathrm{HNO}_{3}$ and $\mathrm{HClO}_{4}(2: 1)$ until clear solutions were obtained and later cooled down to room temperature. Digested samples were then diluted with de-ionized water in $50 \mathrm{~mL}$ volumetric flasks. The concentrations of $\mathrm{Ca}, \mathrm{Mg}$ and $\mathrm{K}$ were analyzed by using an atomic absorption spectrophotometer (Soil and Plant Analysis Council, 1998).

\subsection{Data Analysis}

Completely randomized design was used in this study with 16 seedlings per treatment. The replications were randomly mixed to minimize position effects. Data were analyzed on the effect of treatments on the physical parameters of plant growth and nutrient concentrations in plant tissues using one-way analysis of variance (ANOVA). Mean differences were determined by Tukey's honest significant difference test. The terms were considered significant at $\mathrm{P} \leq 0.05$.

\section{Results and Discussion}

\subsection{Effect of Photoradiation on Temperatures}

Temperature is a plant growth factor that can induce stress in plant when it is too high or too low. Although room temperature was maintained at $16{ }^{\circ} \mathrm{C}$, the temperature above the growing beds differed because of the influence of light intensity and photoperiod. The highest temperature was observed in T5 and T6 $\left(28^{\circ} \mathrm{C}\right.$; Figure 3$)$. The lowest temperature was observed in $\mathrm{T} 3\left(16^{\circ} \mathrm{C}\right)$. Overall, the treatment with a long light period and high light intensity tended to have a high temperature, and vice versa. T6 with the highest treatment temperature resulted in the highest fresh weight of lettuce (156 g). T5 has the same temperature as T6 and yielded lettuce with a fresh weight of $93 \mathrm{~g}$. This variation was due to their different photoperiods of light and dark. T6 had $24 \mathrm{~h}$ of photoperiod, whereas T5 had 45/15 minutes of light/dark photoperiod. Numerous studies have found the effects of temperature on the performance and quality of plant growth. In a study on young tomato, Heuvelink (1989) found that growth conditions at a constant temperature of $24{ }^{\circ} \mathrm{C}$ produced fresh weight of almost four times higher than that of $18{ }^{\circ} \mathrm{C}$, as well as the leave area. Gazula et al. (2005) found that regardless of the lettuce cultivar (Lotto, Valeria and Impuls), temperature-affected anthocyanin and chlorophyll b concentrations were lowest, intermediate and highest at $30 / 30{ }^{\circ} \mathrm{C}$ day/night, $30 / 20{ }^{\circ} \mathrm{C}$ day/night and $20 / 20{ }^{\circ} \mathrm{C}$ day/night respectively. $\mathrm{RH}$ does not affect physiological plant processes, such as photosynthesis or biomass partitioning, except under extreme situations. According to a review on the effects of RH on horticultural crops, the RH of 55 to $90 \%$ at $20{ }^{\circ} \mathrm{C}$ vapour pressure deficit slightly affects the physiology and development of horticultural crops. RH lower than this range may induce plant water stress, which affects plant growth. Higher RH levels cause growth disorders and promote diseases (Grange \& Hand, 1985). In the present study, RH was maintained at $63 \pm 7 \%$ data were taken daily to monitor RH levels in the growth chamber (data not shown). 


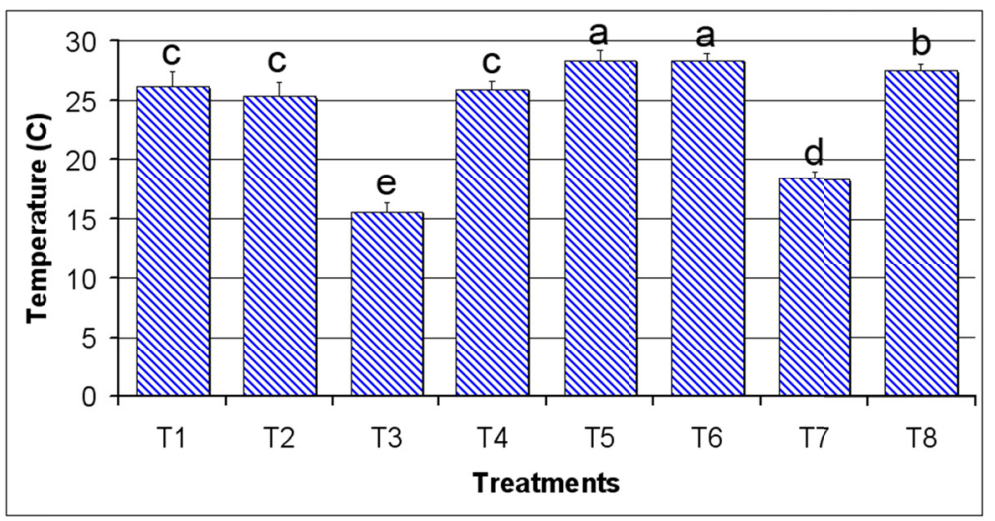

Figure 1. Temperature above growing panels

\subsection{Effect of Photoradiation on Lettuce Growth}

Lettuce showed different responses to photoperiod and light intensity (Figures 2, 3, and 4). The fastest increase in plant height was observed in the T6 with higher intensity and continuously illumination (Figure 2). The increase in photoperiod significantly increased plant height and number of leaves both of lower and higher intensity. The plant height in T3 with lower intensity was greater than that in T2, whereas number of leaves in the former was smaller than that in the latter. When the photoperiod was extended to 45 minutes every hour, the plant height and number of leaves were more significantly reduced in T7 with lower intensity than in T5 with higher intensity. Internode elongation at lower intensity can be reduced by extending the photoperiod. The number of leaves in T5, T6 and T8 were not significantly different. The result indicated that introducing dark periods for higher intensity did not affect leaf emergence, and the number of leaves could be increased by extending the photoperiod under low light intensity conditions. Plant growth in T3 was vertically elongated, and the leaves were not developed perfectly. The plants grown in low light have been frequently shown to be more susceptible to photoinhibition than plants grown under high light intensity (Long, Humphries, \& Falkowski, 1994).

The highest fresh weight was found in the longest photoperiod and higher light intensity (T6, Figure 4). The fresh weight was higher under a long photoperiod than under a shot photoperiod at lower intensity (T3, T4, T7 and T8) and higher intensity (T1, T2, T5 and T6). The fresh weight did not significantly differ between short and long dark periods (T1 and T2, respectively). An extended photoperiod has resulted in an increase in fresh weight for various lettuce cultivars (Koontz \& Prince, 1986). Previous studies showed that increased light intensity usually promotes the growth of lettuce (Hunter \& Burritt, 2004; Li \& Kubota, 2009). Numerous studies reported that the biomass of lettuce increased with extended photoperiods (Ikeda et al., 1987, 1988; Koontz \& Prince, 1986). Kang et al. (2013) showed that maximum light intensity support the increase in plant growth at both short and long photoperiods. In the present study, the lowest fresh weight was observed in T3 with the lowest light intensity and photoperiod. 


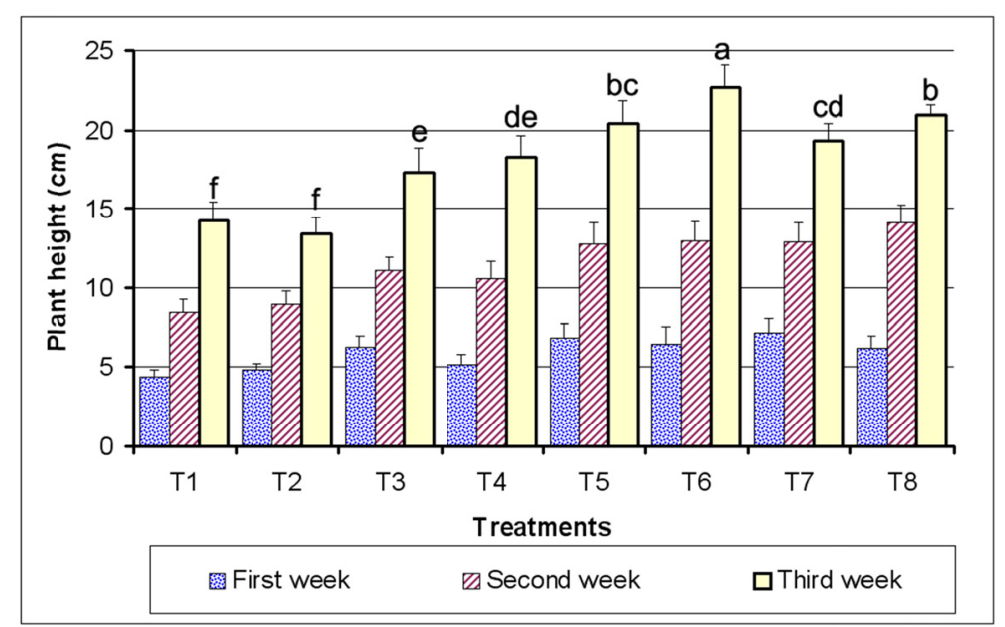

Figure 2. Hight of lettuce measured every week after transplantation

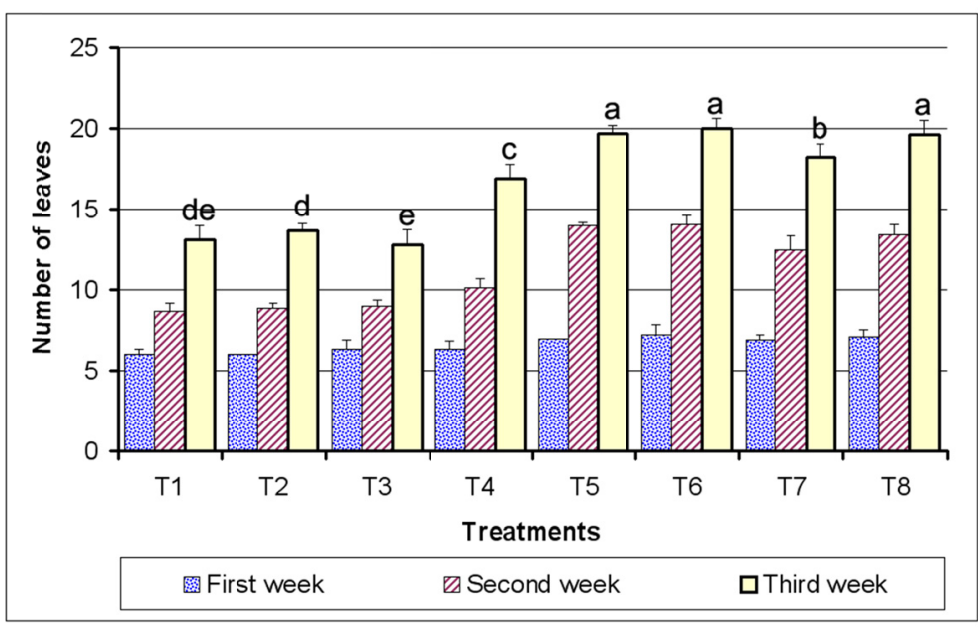

Figure 3. Number of leaves of lettuce counted every week after transplantation

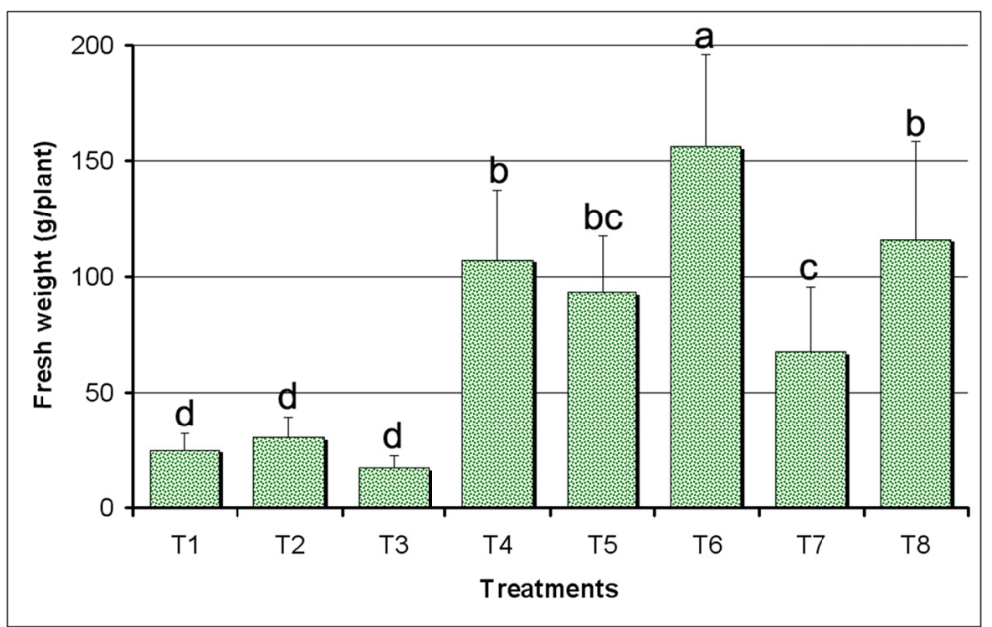

Figure 4. Fresh weight of lettuce measured at harvesting date 


\subsection{Effect of UV Radiation on Plant Growth}

Although UV radiation is known to be harmful to living organism, investigations on the effects of UV on plant biology largely depend on the use of UV-B emitting lamps in both laboratories and field (Atwell, Kriedemann, \& Turnbull, 1999). In the present study, black UV light was added to T4 and T8 (Table 1). T4 and T8 were set with the same intensity and photoperiod by fluorescent lamps, but they were given different black UV light photoperiods. In comparison with T4, T8 showed enhanced fresh weight, plant height, and number of leaves. The shortened black UV radiation promoted the growth performance of the plant (Figures 2, 3, and 4). T8 showed physical damage in the form of the tip of the bottom leaves turning brown (necrosis). Several plant species were reported reacts by changing of leaf color and form. At the onset, bronze or brown spots appear on the leaf surface, and these spots later result in leaf chlorosis, necrosis, and desiccation (Dai et al., 1994; Visser et al., 1997; Kakani, Reddy, Zhao, \& Sailaja, 2003). UV-B radiation damages DNA, proteins, lipids and membranes (Hollósy, 2002). UV-B radiation directly and indirectly affects plants through various processes, including damage to DNA, proteins, and membranes; alterations in transpiration and photosynthesis; and changes in growth, development and morphology (Teramura \& Sullivan, 1994; Jansen, Gaba, \& Greenberg, 1998). However, plant response to $\mathrm{UV}$ radiation varies depending on species or cultivars.

\subsection{Concentrations of $\mathrm{K}, \mathrm{Ca}$ and $\mathrm{Mg}$ in Lettuce Leaves}

Concentrations of $\mathrm{K}, \mathrm{Ca}$ and $\mathrm{Mg}$ in lettuce leaves are shown in Tables 2, 3 and 4, respectively. The concentrations of all elements generally increased from top leaves to bottom leaves. The highest gradient of $\mathrm{K}$ was found in T3, in which the plant received lower light intensity and short duration $\left(6 \mathrm{~h} \mathrm{day}^{-1}\right)$, whereas the lowest gradient was found in T8 with a longer period of fluorescent illumination and shorter UV radiation. High $\mathrm{K}$ concentrations in the bottom leaves were found in $\mathrm{T} 3$, whereas low concentrations in all leaf positions were found in T6, in which plant received higher intensity and continuous illumination. These results indicated that light intensity and duration affected $\mathrm{K}$ movement. High $\mathrm{K}$ accumulation occurred in at low intensity and short photoperiod. $\mathrm{K}$ concentrations at the same position in $\mathrm{T} 1$ and $\mathrm{T} 2$ did not significantly differ, thereby indicating that short and long duration of light and dark periods did not influence $\mathrm{K}$ uptake. The best growth performance of lettuce was found in T6 with the lowest K. No symptom of K deficiency was found in any of the lettuce leaves in this study.

Table 2. Concentrations of $\mathrm{K}$ in lettuce leaves growing under different light conditions (mean $\pm \mathrm{SD}: \mathrm{g} \mathrm{kg}^{-1} \mathrm{dry}$ weight)

\begin{tabular}{|c|c|c|c|c|c|c|c|c|}
\hline \multirow{2}{*}{$\begin{array}{l}\text { Leaf No. } \\
\text { (top to bottom) }\end{array}$} & \multicolumn{8}{|c|}{ Treatments } \\
\hline & 1 & 2 & 3 & 4 & 5 & 6 & 7 & 8 \\
\hline 1 & $53 \pm 3$ & $54 \pm 2$ & $64 \pm 4$ & $69 \pm 7$ & $62 \pm 7$ & $51 \pm 13$ & $60 \pm 11$ & $78 \pm 7$ \\
\hline 2 & $60 \pm 5$ & $61 \pm 4$ & $76 \pm 3$ & $65 \pm 7$ & $63 \pm 5$ & $46 \pm 5$ & $60 \pm 7$ & $81 \pm 11$ \\
\hline 3 & $66 \pm 5$ & $67 \pm 5$ & $84 \pm 6$ & $68 \pm 5$ & $65 \pm 4$ & $45 \pm 7$ & $64 \pm 9$ & $80 \pm 15$ \\
\hline 4 & $73 \pm 5$ & $74 \pm 6$ & $99 \pm 9$ & $69 \pm 6$ & $68 \pm 3$ & $48 \pm 2$ & $66 \pm 5$ & $89 \pm 12$ \\
\hline 5 & $79 \pm 8$ & $82 \pm 2$ & $100 \pm 6$ & $77 \pm 8$ & $78 \pm 9$ & $50 \pm 6$ & $71 \pm 8$ & $84 \pm 14$ \\
\hline 6 & $85 \pm 6$ & $86 \pm 7$ & $111 \pm 15$ & $82 \pm 10$ & $80 \pm 6$ & $48 \pm 4$ & $74 \pm 6$ & $87 \pm 11$ \\
\hline 7 & $89 \pm 9$ & $86 \pm 7$ & $103 \pm 17$ & $80 \pm 10$ & $85 \pm 6$ & $54 \pm 10$ & $73 \pm 8$ & $88 \pm 5$ \\
\hline 8 & $90 \pm 7$ & $92 \pm 5$ & $116 \pm 17$ & $86 \pm 9$ & $88 \pm 3$ & $55 \pm 10$ & $71 \pm 8$ & $82 \pm 7$ \\
\hline 9 & $94 \pm 6$ & $94 \pm 8$ & $118 \pm 17$ & $87 \pm 5$ & $93 \pm 9$ & $60 \pm 14$ & $75 \pm 10$ & $87 \pm 8$ \\
\hline 10 & $93 \pm 9$ & $95 \pm 8$ & $135 \pm 34$ & $84 \pm 8$ & $92 \pm 8$ & $66 \pm 13$ & $78 \pm 9$ & $89 \pm 12$ \\
\hline 11 & & & & $88 \pm 8$ & $98 \pm 14$ & $65 \pm 12$ & $75 \pm 10$ & $82 \pm 13$ \\
\hline 12 & & & & $89 \pm 6$ & $100 \pm 6$ & $68 \pm 12$ & $77 \pm 10$ & $86 \pm 15$ \\
\hline 13 & & & & $87 \pm 13$ & $99 \pm 18$ & $72 \pm 11$ & $77 \pm 12$ & $82 \pm 9$ \\
\hline 14 & & & & $84 \pm 11$ & $97 \pm 5$ & $74 \pm 15$ & $74 \pm 11$ & $91 \pm 9$ \\
\hline 15 & & & & $87 \pm 10$ & $91 \pm 16$ & $76 \pm 8$ & $82 \pm 5$ & $83 \pm 9$ \\
\hline
\end{tabular}

The highest $\mathrm{Ca}$ concentrations were found at first to fourth leaves of $\mathrm{T} 3$, whereas they droped down to lower than T1 and T2 after sixth leaf (Table 3). Ca is a divalent cation and has a less competitive uptake than $\mathrm{K}$. Low $\mathrm{K}$ concentrations in the upper leaves in $\mathrm{T} 3$ allowed a high $\mathrm{Ca}$ uptake, whereas high $\mathrm{K}$ in the lower leaves suppressed $\mathrm{Ca}$ uptake. The highest Ca gradient was found in T2. By contrast, the lowest was found in T6. For the 
same light intensity, a long photoperoid tended to promote Ca uptake. Lettuce required less Ca for its growth in case of higher intensity and continuous illumination (T6).

No symptom of Ca deficiency (tipburn) was encountered in this study. Ca concentrations from the terminal leaves to the bottom leaves in this study ranged from 4.8 to $27.3 \mathrm{~g} \mathrm{~kg}^{-1}$ dry weight. The concentrations in the terminal leaves ranged from 4.8 to $7.8 \mathrm{~g} \mathrm{~kg}^{-1}$ dry weight (Table 3). A previous analysis of the entire leaves at the time of the symptom development found Ca concentrations ranging from 0.5 to $1.7 \mathrm{~g} \mathrm{~kg}^{-1}$ dry weight (Barta \& Tibbitts, 1986, 1991; Collier \& Huntington, 1983; Collier \& Tibbitts, 1984). However, the concentrations of Ca associated with tipburn ranged from 2 to $10 \mathrm{~g} \mathrm{~kg}^{-1}$ dry weight (Yanagi, Bullock, \& Cho, 1983), which is significantly higher than the minimum functional requirement of 1 to $2 \mathrm{~g} \mathrm{~kg}^{-1}$ dry weight suggested by Loneragan and Snowball (1969).

Table 3. Concentrations of $\mathrm{Ca}$ in lettuce leaves growing under different light conditions (mean $\pm \mathrm{SD}: \mathrm{g} \mathrm{kg}^{-1} \mathrm{dry}$ weight)

\begin{tabular}{|c|c|c|c|c|c|c|c|c|}
\hline \multirow{2}{*}{$\begin{array}{l}\text { Leaf No. } \\
\text { (top to bottom) }\end{array}$} & \multicolumn{8}{|c|}{ Treatments } \\
\hline & 1 & 2 & 3 & 4 & 5 & 6 & 7 & 8 \\
\hline 1 & $6.5 \pm 0.9$ & $6.1 \pm 0.8$ & $7.8 \pm 0.9$ & $5.5 \pm 1.1$ & $4.8 \pm 1.0$ & $5.5 \pm 1.5$ & $7.0 \pm 1.2$ & $6.8 \pm 1.4$ \\
\hline 2 & $10.2 \pm 1.3$ & $8.2 \pm 1.2$ & $12.5 \pm 0.9$ & $6.1 \pm 1.0$ & $6.3 \pm 1.4$ & $7.5 \pm 1.2$ & $8.4 \pm 1.3$ & $8.0 \pm 1.8$ \\
\hline 3 & $11.6 \pm 1.6$ & $9.8 \pm 1.0$ & $14.1 \pm 1.0$ & $6.9 \pm 1.3$ & $6.9 \pm 1.7$ & $7.5 \pm 2.1$ & $9.6 \pm 2.0$ & $8.7 \pm 1.9$ \\
\hline 4 & $13.2 \pm 1.4$ & $11.6 \pm 1.2$ & $14.9 \pm 1.0$ & $7.3 \pm 1.6$ & $7.4 \pm 1.5$ & $7.8 \pm 1.3$ & $10.1 \pm 1.8$ & $9.7 \pm 2.0$ \\
\hline 5 & $15.4 \pm 2.0$ & $13.4 \pm 1.2$ & $15.3 \pm 1.3$ & $9.5 \pm 2.4$ & $9.0 \pm 2.6$ & $8.2 \pm 1.4$ & $11.4 \pm 1.2$ & $10.1 \pm 2.0$ \\
\hline 6 & $16.6 \pm 1.1$ & $15.7 \pm 1.4$ & $16.0 \pm 2.3$ & $11.3 \pm 3.0$ & $10.2 \pm 2.3$ & $8.4 \pm 1.7$ & $13.1 \pm 1.7$ & $11.8 \pm 2.4$ \\
\hline 7 & $18.4 \pm 1.4$ & $17.9 \pm 2.6$ & $15.8 \pm 1.6$ & $12.5 \pm 2.4$ & $10.3 \pm 2.0$ & $9.4 \pm 2.8$ & $13.6 \pm 1.6$ & $11.9 \pm 0.9$ \\
\hline 8 & $21.2 \pm 1.0$ & $21.7 \pm 1.9$ & $17.0 \pm 2.7$ & $13.6 \pm 1.7$ & $11.7 \pm 2.7$ & $9.0 \pm 2.5$ & $14.8 \pm 2.7$ & $12.9 \pm 2.0$ \\
\hline 9 & $22.4 \pm 1.2$ & $24.6 \pm 1.6$ & $17.8 \pm 3.4$ & $15.2 \pm 3.2$ & $12.8 \pm 3.1$ & $9.9 \pm 2.1$ & $16.7 \pm 1.6$ & $13.5 \pm 2.0$ \\
\hline 10 & $23.5 \pm 2.0$ & $27.3 \pm 2.7$ & $18.0 \pm 3.2$ & $15.3 \pm 3.3$ & $14.1 \pm 3.0$ & $11.2 \pm 2.8$ & $17.0 \pm 2.3$ & $13.7 \pm 1.6$ \\
\hline 11 & & & & $16.7 \pm 2.1$ & $15.8 \pm 3.0$ & $11.1 \pm 3.3$ & $18.3 \pm 2.3$ & $15.0 \pm 2.6$ \\
\hline 12 & & & & $16.4 \pm 2.6$ & $16.7 \pm 2.5$ & $10.9 \pm 1.0$ & $19.2 \pm 3.3$ & $16.3 \pm 3.6$ \\
\hline 13 & & & & $18.6 \pm 3.2$ & $18.4 \pm 3.3$ & $13.1 \pm 3.5$ & $20.9 \pm 2.5$ & $16.5 \pm 3.5$ \\
\hline 14 & & & & $19.0 \pm 3.1$ & $17.8 \pm 2.7$ & $13.6 \pm 2.3$ & $22.4 \pm 3.2$ & $19.1 \pm 3.8$ \\
\hline 15 & & & & $20.4 \pm 3.0$ & $19.4 \pm 4.1$ & $13.5 \pm 3.2$ & $24.0 \pm 2.9$ & $18.6 \pm 4.5$ \\
\hline
\end{tabular}

The hightest $\mathrm{Mg}$ concentrations were found in the first to fourth leaves of T3 (Table 4), and they were declined to levels lower than those in the bottom leaves of $\mathrm{T} 1$ and $\mathrm{T} 2$. The results indicated antagonistic effect of $\mathrm{K}$ on $\mathrm{Mg}$ similar to that found in case of $\mathrm{Ca}$. The most uniform distribution and less accumulation in the bottom leaves were found in T6 which had the best growth performance. $\mathrm{Mg}$ concentrations in the upper leaves in T1 were higher than those in T2, although both treatments received the same light intensity. Longer photoperoid of light and dark periods promoted $\mathrm{Mg}$ uptake.

The $\mathrm{Mg}$ concentrations in this study ranges from 2.6 to $7.3 \mathrm{~g} \mathrm{~kg}^{-1}$ dry weight. The concentrations were lower than those of $\mathrm{K}$ and $\mathrm{Ca}$. The concentrations of $\mathrm{Mg}$ and $\mathrm{K}$ found in the leaves are typical for lettuce grown under controlled environment conditions (Berry et al., 1981; Barta \& Tibbits, 2000). Barta and Tibbits (1991) found that $\mathrm{Mg}$ concentration is higher than $\mathrm{Ca}$ concentration in tipburned leaves in the range of 2.8 to $6.3 \mathrm{~g} \mathrm{~kg}^{-1} \mathrm{dry}$ weight, with an average of $4.7 \mathrm{~g} \mathrm{~kg}^{-1}$ dry weight. $\mathrm{Mg}$ concentration was fairly lower than Ca concentration because of the absence of tipburn. 
Table 4. Concentrations of $\mathrm{Mg}$ in lettuce leaves growing under different light conditions (mean $\pm \mathrm{SD}: \mathrm{g} \mathrm{kg}^{-1} \mathrm{dry}$ weight)

\begin{tabular}{|c|c|c|c|c|c|c|c|c|}
\hline \multirow{2}{*}{$\begin{array}{l}\text { Leaf No. } \\
\text { (top to bottom) }\end{array}$} & \multicolumn{8}{|c|}{ Treatments } \\
\hline & 1 & 2 & 3 & 4 & 5 & 6 & 7 & 8 \\
\hline 1 & $3.2 \pm 0.2$ & $2.9 \pm 0.2$ & $3.8 \pm 0.3$ & $3.0 \pm 0.3$ & $2.7 \pm 0.3$ & $2.9 \pm 0.5$ & $3.3 \pm 0.5$ & $3.7 \pm 0.3$ \\
\hline 2 & $4.0 \pm 0.4$ & $3.2 \pm 0.3$ & $4.9 \pm 0.5$ & $2.6 \pm 0.3$ & $2.6 \pm 0.3$ & $2.9 \pm 0.3$ & $3.2 \pm 0.4$ & $3.4 \pm 0.3$ \\
\hline 3 & $4.3 \pm 0.5$ & $3.5 \pm 0.2$ & $5.3 \pm 0.6$ & $2.6 \pm 0.3$ & $2.7 \pm 0.4$ & $2.9 \pm 0.6$ & $3.5 \pm 0.4$ & $3.4 \pm 0.4$ \\
\hline 4 & $4.8 \pm 0.4$ & $4.0 \pm 0.4$ & $5.5 \pm 0.6$ & $2.6 \pm 0.4$ & $2.7 \pm 0.5$ & $3.0 \pm 0.3$ & $3.7 \pm 0.4$ & $3.4 \pm 0.3$ \\
\hline 5 & $5.3 \pm 0.6$ & $4.4 \pm 0.2$ & $5.2 \pm 0.2$ & $3.0 \pm 0.6$ & $3.0 \pm 0.7$ & $3.1 \pm 0.4$ & $3.9 \pm 0.4$ & $3.7 \pm 0.8$ \\
\hline 6 & $5.6 \pm 0.3$ & $4.9 \pm 0.4$ & $5.1 \pm 0.5$ & $3.7 \pm 1.0$ & $3.4 \pm 0.6$ & $3.1 \pm 0.4$ & $4.4 \pm 0.5$ & $3.8 \pm 0.4$ \\
\hline 7 & $5.7 \pm 0.3$ & $5.4 \pm 0.6$ & $5.1 \pm 1.0$ & $3.4 \pm 0.5$ & $3.2 \pm 0.5$ & $3.4 \pm 0.8$ & $4.5 \pm 0.5$ & $3.8 \pm 0.2$ \\
\hline 8 & $6.3 \pm 0.3$ & $6.3 \pm 0.3$ & $4.8 \pm 0.8$ & $3.7 \pm 0.3$ & $3.6 \pm 0.6$ & $3.2 \pm 0.7$ & $4.7 \pm 0.8$ & $4.0 \pm 0.6$ \\
\hline 9 & $6.2 \pm 0.4$ & $7.1 \pm 0.8$ & $4.8 \pm 1.0$ & $4.0 \pm 0.8$ & $4.5 \pm 2.6$ & $3.4 \pm 0.5$ & $5.3 \pm 0.7$ & $4.0 \pm 0.5$ \\
\hline 10 & $5.8 \pm 0.7$ & $7.3 \pm 0.4$ & $4.6 \pm 0.7$ & $4.0 \pm 0.8$ & $4.0 \pm 0.5$ & $3.7 \pm 0.6$ & $5.3 \pm 1.0$ & $4.0 \pm 0.4$ \\
\hline 11 & & & & $4.4 \pm 0.5$ & $4.5 \pm 0.7$ & $3.7 \pm 0.7$ & $5.5 \pm 0.9$ & $4.4 \pm 0.6$ \\
\hline 12 & & & & $4.1 \pm 0.5$ & $4.6 \pm 0.4$ & $3.6 \pm 0.2$ & $5.6 \pm 1.2$ & $4.5 \pm 0.6$ \\
\hline 13 & & & & $4.9 \pm 0.8$ & $4.9 \pm 0.8$ & $4.0 \pm 0.6$ & $5.7 \pm 0.6$ & $4.6 \pm 0.7$ \\
\hline 14 & & & & $4.8 \pm 0.9$ & $4.8 \pm 0.4$ & $3.8 \pm 0.7$ & $6.0 \pm 1.0$ & $5.1 \pm 0.8$ \\
\hline 15 & & & & $5.2 \pm 0.8$ & $4.9 \pm 0.8$ & $4.1 \pm 0.8$ & $6.0 \pm 0.8$ & $4.7 \pm 0.7$ \\
\hline
\end{tabular}

\subsection{Distribution of Cation Ratios ( $\mathrm{K} / \mathrm{Ca}, \mathrm{K} / \mathrm{Mg}$ and $\mathrm{Ca} / \mathrm{Mg}$ )}

The mole ratio of $\mathrm{K} / \mathrm{Ca}$ in the nutrient solution was 1.33 , which was lower than the ratios in the lettuce leaves in all of the treatments (Table 5). The mole ratios were found in the range of 3.5 to 13.5. The ratios in younger leaves were higher than those in older leaves. These results indicated that $\mathrm{K}$ uptake in lettuce was faster than Ca uptake. High mole ratios were found in the younger leaves of T4, T8, and T5. T6 which gave the best growth performance showed a high mole ratio in the terminal leaf, whereas the raios in older leaves varied in a small range (5.9 to 6.5). High light intensity and continuous radiation increased temperature and transpiration rate in the plants and the $\mathrm{Ca}$ uptake in T6. Both high and low $\mathrm{K} / \mathrm{Ca}$ mole ratios affected plant growth and development. Mortensen, Ottosen, and Gislerød (2001) found that decreasing of $\mathrm{K} / \mathrm{Ca}$ in fertilizer composition from high to low (42:1 to 1:5) delays the flowering of pot rose.

Table 5. $\mathrm{K} / \mathrm{Ca}$ mole ratios in lettuce leaves growing under different light conditions (mean $\pm \mathrm{SD}$ )

\begin{tabular}{lllllllll}
\hline \multirow{2}{*}{$\begin{array}{l}\text { Leaf No. } \\
\text { (top to bottom) }\end{array}$} & 1 & 2 & 3 & 4 & 5 & 6 & 7 & 8 \\
\hline 1 & $8.5 \pm 1.0$ & $9.3 \pm 1.2$ & $8.6 \pm 1.3$ & $13.1 \pm 1.5$ & $13.5 \pm 1.8$ & $9.8 \pm 2.0$ & $8.9 \pm 1.3$ & $12.9 \pm 1.2$ \\
2 & $6.1 \pm 0.6$ & $7.7 \pm 1.1$ & $6.3 \pm 0.4$ & $11.1 \pm 1.6$ & $10.7 \pm 2.3$ & $6.2 \pm 1.1$ & $7.5 \pm 1.4$ & $10.2 \pm 1.8$ \\
3 & $5.9 \pm 0.7$ & $7.0 \pm 0.7$ & $6.1 \pm 0.5$ & $10.2 \pm 1.5$ & $9.6 \pm 2.1$ & $5.9 \pm 1.2$ & $7.1 \pm 1.6$ & $9.1 \pm 1.2$ \\
4 & $5.7 \pm 0.7$ & $6.6 \pm 0.5$ & $6.8 \pm 0.7$ & $10.0 \pm 1.6$ & $9.7 \pm 1.9$ & $6.4 \pm 0.9$ & $6.9 \pm 1.3$ & $9.6 \pm 1.3$ \\
5 & $5.3 \pm 0.3$ & $6.3 \pm 0.6$ & $6.8 \pm 0.5$ & $8.7 \pm 1.8$ & $9.3 \pm 1.8$ & $6.4 \pm 0.8$ & $6.4 \pm 0.7$ & $9.3 \pm 1.8$ \\
6 & $5.3 \pm 0.5$ & $5.6 \pm 0.2$ & $7.2 \pm 0.9$ & $6.9 \pm 1.6$ & $8.3 \pm 1.3$ & $6.1 \pm 1.1$ & $5.9 \pm 1.1$ & $7.5 \pm 1.5$ \\
7 & $4.9 \pm 0.4$ & $5.0 \pm 0.7$ & $6.8 \pm 0.9$ & $6.7 \pm 1.2$ & $8.7 \pm 1.3$ & $6.1 \pm 1.5$ & $5.6 \pm 0.8$ & $7.6 \pm 0.6$ \\
8 & $4.3 \pm 0.3$ & $4.4 \pm 0.3$ & $7.1 \pm 1.6$ & $6.6 \pm 0.7$ & $7.9 \pm 1.5$ & $6.5 \pm 1.5$ & $5.0 \pm 1.0$ & $6.7 \pm 1.5$ \\
9 & $4.3 \pm 0.3$ & $4.0 \pm 0.5$ & $7.1 \pm 1.7$ & $6.1 \pm 1.2$ & $7.7 \pm 1.3$ & $6.3 \pm 1.0$ & $4.7 \pm 0.8$ & $6.7 \pm 0.8$ \\
10 & $4.0 \pm 0.4$ & $3.7 \pm 0.5$ & $7.1 \pm 1.7$ & $5.9 \pm 1.3$ & $6.9 \pm 1.2$ & $6.2 \pm 1.1$ & $4.8 \pm 1.1$ & $6.7 \pm 1.1$ \\
11 & & & & $5.5 \pm 0.8$ & $6.6 \pm 1.5$ & $6.3 \pm 1.3$ & $4.3 \pm 0.9$ & $5.7 \pm 1.0$ \\
12 & & & $5.7 \pm 1.4$ & $6.2 \pm 0.8$ & $6.4 \pm 0.7$ & $3.9 \pm 0.5$ & $6.2 \pm 1.1$ \\
13 & & & $4.8 \pm 1.4$ & $5.7 \pm 1.4$ & $5.9 \pm 1.2$ & $3.7 \pm 0.8$ & $5.2 \pm 1.0$ \\
14 & & & & $4.7 \pm 1.1$ & $5.7 \pm 0.9$ & $6.3 \pm 1.4$ & $3.5 \pm 0.8$ & $5.0 \pm 1.0$ \\
15 & & & & $4.5 \pm 1.1$ & $5.3 \pm 1.1$ & $5.9 \pm 0.9$ & $3.5 \pm 0.5$ & $4.8 \pm 1.3$ \\
\hline
\end{tabular}


The $\mathrm{K} / \mathrm{Mg}$ mole ratio in the nutrient solution was 3.0, whereas the ratios in the lettuce leaves of all treatments were varies from 7.4 to 18.4 (Table 6), thereby indicating that $\mathrm{K}$ uptake was faster than $\mathrm{Mg}$ uptake. The $\mathrm{K} / \mathrm{Mg}$ increased rapidly from the upper leaves to the bottom leaves in $\mathrm{T} 3$, due to accumulation of $\mathrm{K}$ in the bottom leaves. The accumulation may be occurred due to insufficiency of light energy and low temperature above the growing panel. $\mathrm{The} \mathrm{K} / \mathrm{Mg}$ in T6 varied in a narrow range of 9.7 to 12.2 through all levels of the leaves. The $\mathrm{K} / \mathrm{Mg}$ ratios in T5 were higher than in T6, and a large difference between the 2 treatments occurred in upper leaves. A short photoperiod of T5 reduced Mg uptake and plant growth.

Table 6. $\mathrm{K} / \mathrm{Mg}$ mole rations in lettuce leaves growing under different light conditions (mean $\pm \mathrm{SD}$ )

\begin{tabular}{lllllllll}
\hline $\begin{array}{l}\text { Leave No. } \\
\text { (top to bottom) }\end{array}$ & 1 & 2 & 3 & 4 & 5 & 6 & 7 & 8 \\
\hline 1 & $10.5 \pm 0.5$ & $11.5 \pm 0.7$ & $10.6 \pm 0.7$ & $14.4 \pm 0.5$ & $14.2 \pm 0.9$ & $10.9 \pm 2.0$ & $11.2 \pm 1.3$ & $13.3 \pm 1.5$ \\
2 & $9.5 \pm 0.6$ & $11.7 \pm 0.8$ & $9.6 \pm 0.8$ & $15.9 \pm 1.0$ & $15.3 \pm 1.9$ & $9.7 \pm 1.2$ & $11.9 \pm 1.7$ & $14.6 \pm 1.6$ \\
3 & $9.6 \pm 0.8$ & $11.8 \pm 0.5$ & $9.9 \pm 0.7$ & $16.3 \pm 1.0$ & $15.4 \pm 2.0$ & $9.9 \pm 2.0$ & $11.8 \pm 1.8$ & $14.7 \pm 1.4$ \\
4 & $9.5 \pm 1.1$ & $11.5 \pm 0.6$ & $11.2 \pm 0.8$ & $16.9 \pm 1.7$ & $16.1 \pm 2.3$ & $10.1 \pm 0.9$ & $11.3 \pm 1.3$ & $16.1 \pm 1.0$ \\
5 & $9.4 \pm 0.6$ & $11.6 \pm 0.7$ & $12.0 \pm 0.9$ & $16.1 \pm 1.7$ & $16.5 \pm 2.0$ & $10.1 \pm 0.6$ & $11.2 \pm 1.3$ & $16.2 \pm 2.6$ \\
6 & $9.9 \pm 1.0$ & $10.8 \pm 0.4$ & $13.4 \pm 0.8$ & $14.5 \pm 2.6$ & $15.2 \pm 2.6$ & $9.7 \pm 1.1$ & $10.5 \pm 1.7$ & $14.2 \pm 1.3$ \\
7 & $9.7 \pm 1.2$ & $10.0 \pm 1.0$ & $12.9 \pm 2.2$ & $14.8 \pm 2.0$ & $16.6 \pm 1.7$ & $10.2 \pm 1.9$ & $10.3 \pm 1.5$ & $14.6 \pm 1.3$ \\
8 & $8.8 \pm 0.5$ & $9.2 \pm 0.4$ & $15.8 \pm 2.9$ & $14.6 \pm 1.2$ & $15.8 \pm 2.7$ & $11.0 \pm 2.2$ & $9.6 \pm 1.9$ & $13.2 \pm 2.4$ \\
9 & $9.5 \pm 1.2$ & $8.8 \pm 0.7$ & $15.3 \pm 2.4$ & $13.5 \pm 2.3$ & $15.9 \pm 1.6$ & $10.8 \pm 1.6$ & $8.9 \pm 1.5$ & $13.5 \pm 1.7$ \\
10 & $9.6 \pm 1.0$ & $8.2 \pm 0.7$ & $18.4 \pm 3.7$ & $14.4 \pm 1.8$ & $14.4 \pm 1.9$ & $11.1 \pm 1.5$ & $8.6 \pm 1.0$ & $13.1 \pm 2.0$ \\
11 & & & & $12.8 \pm 2.2$ & $13.8 \pm 2.8$ & $11.1 \pm 1.8$ & $8.6 \pm 1.9$ & $11.8 \pm 2.1$ \\
12 & & & & $13.6 \pm 2.3$ & $13.6 \pm 1.1$ & $11.9 \pm 1.9$ & $8.0 \pm 0.9$ & $13.1 \pm 2.0$ \\
13 & & & & $10.5 \pm 1.3$ & $12.0 \pm 2.5$ & $11.4 \pm 2.0$ & $8.1 \pm 1.5$ & $11.2 \pm 1.8$ \\
14 & & & & $11.9 \pm 2.4$ & $12.7 \pm 0.9$ & $12.6 \pm 1.7$ & $7.4 \pm 1.6$ & $11.4 \pm 2.0$ \\
15 & & & & $9.9 \pm 2.1$ & $11.1 \pm 2.6$ & $11.5 \pm 1.8$ & $8.6 \pm 1.3$ & $11.1 \pm 2.2$ \\
\hline
\end{tabular}

Concentrations of $\mathrm{Ca}$ and $\mathrm{Mg}$ in nutrient solution were 4.5 and $2.0 \mathrm{mmole} \cdot \mathrm{L}^{-1}$, respectively; yielding $\mathrm{Ca} / \mathrm{Mg}$ ratio of 2.25 . The $\mathrm{Ca} / \mathrm{Mg}$ ratios in lettuce leaves ranged from 1.1 to 2.5 , and gradually increased from the top leaves to the bottom leaves (Table 7). The $\mathrm{Ca} / \mathrm{Mg}$ ratios in the upper leaves were lower than those in the solution. The results indicated that $\mathrm{Mg}$ uptake in lettuce was faster than $\mathrm{Ca}$ uptake. An accumulation of $\mathrm{Ca}$ in bottom leaves increased the $\mathrm{Ca} / \mathrm{Mg}$ ratios above 2.25 . The $\mathrm{Ca} / \mathrm{Mg}$ in $\mathrm{T} 6$ tended to be lower than the other treatments except in the first and second leaves. High light intensity and continuous illumination reduced $\mathrm{Ca}$ accumulation. At a high $\mathrm{Mg}$ supply, leaf $\mathrm{Mg}$ concentration significantly reduced when $\mathrm{Ca}$ supply was also high. At a low $\mathrm{Mg}$ supply, Ca supply does not significantly affect Mg concentration in leaves (Rios et al., 2012).

Table 7. $\mathrm{Ca} / \mathrm{Mg}$ mole ratios in lettuce leaves growing under different light conditions (mean $\pm \mathrm{SD}$ )

\begin{tabular}{|c|c|c|c|c|c|c|c|c|}
\hline \multirow{2}{*}{$\begin{array}{l}\text { Leave No. } \\
\text { (top to bottom) }\end{array}$} & \multicolumn{8}{|c|}{ Treatments } \\
\hline & 1 & 2 & 3 & 4 & 5 & 6 & 7 & 8 \\
\hline 1 & $1.2 \pm 0.1$ & $1.3 \pm 0.1$ & $1.2 \pm 0.2$ & $1.1 \pm 0.1$ & $1.1 \pm 0.1$ & $1.1 \pm 0.1$ & $1.3 \pm 0.2$ & $1.1 \pm 0.1$ \\
\hline 2 & $1.6 \pm 0.1$ & $1.5 \pm 0.1$ & $1.5 \pm 0.2$ & $1.4 \pm 0.2$ & $1.5 \pm 0.2$ & $1.5 \pm 0.1$ & $1.6 \pm 0.2$ & $1.4 \pm 0.3$ \\
\hline 3 & $1.6 \pm 0.1$ & $1.7 \pm 0.1$ & $1.6 \pm 0.2$ & $1.6 \pm 0.2$ & $1.6 \pm 0.2$ & $1.5 \pm 0.2$ & $1.6 \pm 0.2$ & $1.6 \pm 0.2$ \\
\hline 4 & $1.7 \pm 0.1$ & $1.8 \pm 0.1$ & $1.7 \pm 0.2$ & $1.7 \pm 0.2$ & $1.7 \pm 0.2$ & $1.6 \pm 0.1$ & $1.7 \pm 0.2$ & $1.7 \pm 0.2$ \\
\hline 5 & $1.8 \pm 0.1$ & $1.8 \pm 0.1$ & $1.8 \pm 0.2$ & $1.9 \pm 0.2$ & $1.8 \pm 0.2$ & $1.6 \pm 0.1$ & $1.8 \pm 0.1$ & $1.8 \pm 0.1$ \\
\hline 6 & $1.7 \pm 0.3$ & $1.9 \pm 0.0$ & $1.9 \pm 0.2$ & $2.1 \pm 0.2$ & $1.8 \pm 0.2$ & $1.6 \pm 0.2$ & $1.8 \pm 0.1$ & $1.9 \pm 0.3$ \\
\hline 7 & $2.0 \pm 0.2$ & $2.0 \pm 0.1$ & $1.9 \pm 0.3$ & $2.2 \pm 0.2$ & $1.9 \pm 0.2$ & $1.7 \pm 0.2$ & $1.9 \pm 0.1$ & $1.9 \pm 0.1$ \\
\hline 8 & $2.0 \pm 0.1$ & $2.1 \pm 0.1$ & $2.2 \pm 0.2$ & $2.2 \pm 0.1$ & $2.0 \pm 0.2$ & $1.7 \pm 0.2$ & $1.9 \pm 0.1$ & $2.0 \pm 0.2$ \\
\hline 9 & $2.2 \pm 0.2$ & $2.1 \pm 0.3$ & $2.3 \pm 0.2$ & $2.2 \pm 0.2$ & $1.9 \pm 0.4$ & $1.7 \pm 0.2$ & $1.9 \pm 0.1$ & $2.0 \pm 0.2$ \\
\hline 10 & $2.5 \pm 0.4$ & $2.3 \pm 0.2$ & $2.4 \pm 0.2$ & $2.3 \pm 0.2$ & $2.1 \pm 0.2$ & $1.8 \pm 0.2$ & $1.9 \pm 0.1$ & $2.1 \pm 0.2$ \\
\hline 11 & & & & $2.3 \pm 0.2$ & $2.1 \pm 0.2$ & $1.8 \pm 0.2$ & $2.0 \pm 0.2$ & $2.1 \pm 0.2$ \\
\hline 12 & & & & $2.4 \pm 0.2$ & $2.2 \pm 0.2$ & $1.9 \pm 0.2$ & $2.1 \pm 0.2$ & $2.2 \pm 0.2$ \\
\hline 13 & & & & $2.4 \pm 0.3$ & $2.3 \pm 0.2$ & $2.0 \pm 0.3$ & $2.2 \pm 0.3$ & $2.2 \pm 0.2$ \\
\hline 14 & & & & $2.4 \pm 0.2$ & $2.3 \pm 0.3$ & $2.0 \pm 0.3$ & $2.3 \pm 0.3$ & $2.3 \pm 0.2$ \\
\hline 15 & & & & $2.4 \pm 0.1$ & $2.4 \pm 0.2$ & $2.0 \pm 0.2$ & $2.5 \pm 0.4$ & $2.4 \pm 0.3$ \\
\hline
\end{tabular}




\section{Conclusion}

A longer photoperiod and higher light intensity improved plant growth and development. These conditions gave the greatest shoot fresh weight, plant height, and number of leaves. Whereas a short photoperiod and lower light intensity gave the lowest shoot fresh weight. Shortened UV light radiation led to better result in lettuce growth performance such as shoot fresh weight, plant height and number of leaves. UV light also damaged the lettuce leave; that is, the tip of the old leaves turned brown spot. Molar concentrations of $\mathrm{K}, \mathrm{Ca}$ and $\mathrm{Mg}$ in lettuce leaves were in an order of $\mathrm{K}>\mathrm{Ca}>\mathrm{Mg}$ for all of the light treatments. The steep gradient and highest $\mathrm{K}$ accumulation in the bottom leaves were found in lower light intensity $\left(128 \mu \mathrm{mol} \mathrm{m}^{-2} \mathrm{~s}^{-1}\right)$ and short photoperiod $\left(6 \mathrm{~h} \mathrm{day}^{-1}\right)$. Extended photoperiod improved $\mathrm{K}$ and $\mathrm{Ca}$ movement and reduced $\mathrm{K}$ and $\mathrm{Ca}$ accumulation in the bottom leaves. High K in the leaves reduced Ca uptake. Continuous illumination at $194 \mu \mathrm{mol} \mathrm{m}{ }^{-2} \mathrm{~s}^{-1}$ resulted in the lowest concentrations of $\mathrm{K}, \mathrm{Ca}$ and $\mathrm{Mg}$ and the greatest growth performance. The mole ratio of $\mathrm{K} / \mathrm{Ca}$ decreased from the top leaves to the bottom leaves, whereas $\mathrm{K} / \mathrm{Mg}$ tended to be steady except for the treatment of lower light intensity and short photoperoid. The best growth performance was found in the treatment with a steady $\mathrm{K} / \mathrm{Ca}$ ratio.

\section{References}

Atwell, B. J., Kriedemann, P. E., \& Turnbull, C. G. (1999). Plants in action: Adaptation in nature, performance in cultivation. Macmillan Education AU. Retrieved from http://plantsinaction.science.uq.edu.au

Barta, D. J., \& Tibbitts, T. W. (1986). Effects of Artificial Enclosure of Young Lettuce Leaves on Tipbum Incidence and Leaf Calcium. American Society for Horticultural Science, 150(3), 413-416.

Barta, D. J., \& Tibbitts, T. W. (1991). Calcium localization in lettuce leaves with and without tipburn: Comparison of controlled-environment and field-grown plants. American Society for Horticultural Science, $116(5), 870-875$.

Barta, D. J., \& Tibbitts, T. W. (2000). Calcium localization and tipburn development in lettuce leaves during early enlargement. American Society for Horticultural Science, 125(3), 294-298.

Berry, W. L., Krizek, D. T., Ormrod, D. P., McFarlane, J. C., Langhans, R. W., \& Tibbitts, T. W. (1981). Variation in elemental content of lettuce grown under base-line conditions in five controlled-environment facilities. American Society for Horticultural Science, 106, 661-666.

Collier, G. F., \& Huntington, V. C. (1983). The relationship between leaf growth, calcium accumulation and distribution, and tipburn development in field-grown butterhead lettuce. Scientia Horticulturae, 21(2), 123-128. https://doi.org/10.1016/0304-4238(83)90157-7

Collier, G. F., \& Tibbitts, T. W. (1984). Effects of relative humidity and root temperature on calcium concentration and tipburn development in lettuce. American Society for Horticultural Science, 109(2), 128-131.

Dai, Q., Shaobing, P., Chavez, A. Q., \& Vergara, B. S. (1994). Intraspecific responses of 188 rice cultivars to enhanced UV-B radiation. Environmental and Experimental Botany, 34(4), 433-442. https://doi.org/ $10.1016 / 0098-8472(94) 90026-4$

Hao, X., \& Papadopoulos, A. P. (2003). Effects of calcium and magnesium on growth, fruit yield and quality in a greenhouse tomato crop grown on rockwool. Can. J. Plant Sci., 83, 903-912. https://doi.org/10.4141/ $\mathrm{P} 02-140$

Hollósy, F. (2002). Effects of ultraviolet radiation on plant cells. Micron, 33(2), 179-197. https://doi.org/10.1016/ S0968-4328(01)00011-7

Hopkins, W. G., \& Hüner, N. P. A. (2004). Introduction to plant physiology (3rd ed.). New York. NY: Wiley \& Sons.

Hunter, D. C., \& Burritt, D. J. (2004). Light quality influences adventitious shoot production from cotyledon explants of lettuce (Lactuca sativa L.). In Vitro Cellular and Developmental Biology-Plant, 40(2), 215-220. https://doi.org/10.1079/IVP2003492

Ikeda, A., Nakayama, S., Kitaya, Y., \& Yabuki, K. (1987). Effects of photoperiod, $\mathrm{CO}_{2}$ concentration, and light intensity on growth and net photosynthetic rates of lettuce and turnip (pp. 273-282). Symposium on Biological Aspects of Energy Saving in Protected Cultivation, 229. 
Ikeda, A., Nakayama, S., Kitaya, Y., \& Yabuki, K. (1988). Basic study on material production in plant factory-Effects of photoperiod, light intensity, and $\mathrm{CO}_{2}$ concentration on photosynthesis of lettuce. Environ. Control Biol., 26, 107-112. https://doi.org/10.2525/ecb1963.26.113

Jansen, M. A., Gaba, V., \& Greenberg, B. M. (1998). Higher plants and UV-B radiation: Balancing damage, repair and acclimation. Trends in Plant Science, 3(4), 131-135. https://doi.org/10.1016/S1360-1385 (98)01215-1

Kakani, V. G., Reddy, K. R., Zhao, D., \& Sailaja, K. (2003). Field crop responses to ultraviolet-B radiation: A review. Agricultural and Forest Meteorology, 120(1), 191-218. https://doi.org/10.1016/j.agrformet.2003. 08.015

Kang, J. H., Krishna Kumar, S., Atulba, S. L. S., Jeong, B. R., \& Hwang, S. J. (2013). Light intensity and photoperiod influence the growth and development of hydroponically grown leaf lettuce in a closed-type plant factory system. Horticulture, Environment, and Biotechnology, 54(6), 501-509. https://doi.org/ 10.1007/s13580-013-0109-8

Koontz, H. V., \& Prince, R. P. (1986). Effect of 16 and 24 hours daily radiation (light) on lettuce growth. HortScience: a publication of the American Society for Horticultural Science, 21(1), 123-124.

Kozai, T. (2013). Resource use efficiency of closed plant production system with artificial light: Concept, estimation and application to plant factory. Proc. Jpn. Acad., Ser. B 89, 447-461. https://doi.org/10.2183/ pjab.89.447

Li, Q., \& Kubota, C. (2009). Effects of supplemental light quality on growth and phytochemicals of baby leaf lettuce. Environmental and Experimental Botany, 67(1), 59-64. https://doi.org/10.1016/j.envexpbot. 2009.06.011

Loneragan, J. F., \& Snowball, K. (1969). Calcium requirements of plants. Crop and Pasture Science, 20(3), 465-478. https://doi.org/10.1071/AR9690465

Long, S. P., Humphries, S., \& Falkowski, P. G. (1994). Photoinhibition of photosynthesis in nature. Annual Review of Plant Biology, 45(1), 633-662. https://doi.org/10.1146/annurev.pp.45.060194.003221

Mortensen, L. M., Ottosen, C. O., \& Gislerød, H. R. (2001). Effects of air humidity and K:Ca ratio on growth, morphology, flowering and keeping quality of pot roses. Scientia Horticulturae, 90(1), 131-141. https://doi.org/10.1016/S0304-4238(00)00251-X

Rios, J. J., O’Lochlainn, S., Devonshire, J., Graham, N. S., Hammond, J. P., King, G. J., ... Broadley, M. R. (2012). Distribution of calcium (Ca) and magnesium $(\mathrm{Mg})$ in the leaves of Brassica rapa under varying exogenous Ca and Mg supply. Annals of Botany, 109, 1081-1089. https://doi.org/10.1093/ aob/mcs029

Soil and Plant Analysis Council. (1998). Handbook of Reference Methods for Plant Analysis. Boca Raton, America: CRC Press.

Teramura, A. H., \& Sullivan, J. H. (1994). Effects of UV-B radiation on photosynthesis and growth of terrestrial plants. Photosynthesis Research, 39(3), 463-473. https://doi.org/10.1007/BF00014599

Visser, A. J., Tosserams, M., Groen, M. W., Kalis, G., Kwant, R., Magendans, G. W. H., \& Rozema, J. (1997). The combined effects of $\mathrm{CO}_{2}$ concentration and enhanced UV-B radiation on faba bean. 3. Leaf optical properties, pigments, stomatal index and epidermal cell density. UV-B and biosphere (pp. 208-222). Springer Netherlands. https://doi.org/10.1007/978-94-011-5718-6_19

Yanagi, A. A., Bullock, R. M., \& Cho, J. J. (1983). Factors involved in the development of tipburn in crisphead lettuce in Hawaii. American Society for Horticultural Science, 108(2), 234-237.

\section{Copyrights}

Copyright for this article is retained by the author(s), with first publication rights granted to the journal.

This is an open-access article distributed under the terms and conditions of the Creative Commons Attribution license (http://creativecommons.org/licenses/by/4.0/). 